\title{
Optimization of seasonal storage for community-level energy systems: status and needs
}

\author{
Seama Koohi-Fayegh ${ }^{1} \cdot$ Marc A. Rosen $^{1}$ \\ ${ }^{1}$ Faculty of Engineering and Applied Science, University of Ontario Institute of Technology, 2000 Simcoe Street North, Oshawa, ON L1H 7K4, \\ Canada
}

Received: 24 November 2015/Revised: 23 January 2017/ Accepted: 7 February 2017/Published online: 21 February 2017

(C) Joint Center on Global Change and Earth System Science of the University of Maryland and Beijing Normal University and Springer-Verlag Berlin Heidelberg 2017

\begin{abstract}
The status and needs relating to the optimal design of community seasonal energy storage are reported. Thermal energy storage research has often focused on technology development and integration into buildings, but little emphasis has been placed on the most advantageous use of thermal storage in community energy systems. Depending on the composition and characteristics of a community, the most appropriate community thermal storage may differ from that for a single building. District energy systems usually link thermal users to cold supplies and/or heat supplies (e.g., solar thermal energy, geothermal energy from ground-source heat pumps or geothermal hot zones, industrial waste heat, thermal energy from cogeneration or trigeneration). It is demonstrated that the optimal integration of these technologies can be enhanced through the use of appropriate seasonal thermal energy storage and that community-level seasonal storage can facilitate the development of smart net-zero energy buildings and yield efficiency, economic and environmental benefits. Issues that need to be resolved to allow optimal solutions to be attained are described. Advanced tools are required for modeling, simulation, analysis, improvement, design and optimization, which incorporate advanced methods like exergy analysis. The most appropriate scale, number and type (e.g., sensible, latent, thermochemical) of thermal storages in a community need to be better assessed, and the appropriate time duration capacities for each determined in an optimal manner. This is particularly important since a
\end{abstract}

Seama Koohi-Fayegh

Sima.Kouhi@uoit.ca

Marc A. Rosen

Marc.Rosen@uoit.ca combination of short-, medium- and long-term storage is sometimes required to yield the most benefits from community energy systems.

Keywords Thermal storage - Community energy system . Integration

\section{Introduction}

As research aimed at nearing or achieving net-zero energy buildings and communities intensifies, governments are promoting the adoption of renewable energy sources in buildings in the commercial, institutional, industrial and residential sectors. Thermal energy storage (TES) is a useful technology for storing thermal energy (heat or cold) between periods when it is available and periods when it is needed and thus facilitates the integration of renewable energy into communities (on the generation side) and acts as a buffer that permits the user-demand variability in communities to be satisfied (on the demand side).

Although much research on thermal energy storage often focuses on the development of storage technologies and some focuses on the integration of storages into buildings, much less emphasis has been placed on the most advantageous use of TES in community energy systems. Depending on the composition and characteristics of a community, the most appropriate thermal storage for a community may differ from that for a single building.

A community-level thermal storage can be integrated into a community serving many users and multiple thermal energy suppliers of thermal energy. The thermal energy can be above environmental temperatures (i.e., hot) or below 
environmental temperatures (i.e., cold). Thermal energy users can be in the form of a wide range of building types (Heier et al. 2015). Heat suppliers can include solar thermal energy, geothermal energy from ground-source heat pumps or geothermal hot zones, industrial waste heat, thermal energy from cogeneration or trigeneration systems and others. Cold suppliers usually include dedicated cooling facilities.

The linkages between thermal energy users (buildings) and thermal energy suppliers are often accomplished using thermal grids, i.e., district heating and/or cooling systems. Various heat users (i.e., commercial, industrial and residential buildings) require heat at a range of temperatures depending on the indoor temperature demands as well as the heating technologies used in the building. TES systems are selected according to such specific applications. For example, underground thermal energy storage (UTES) systems operate more efficiently with lower-temperature requirements for space heating and higher-temperature requirements for space cooling. In commercial and institutional buildings that use thermo-active building systems (TABS) or in residential buildings that use floor heating systems, UTES systems can be an appropriate choice to be integrated with such low-temperature heating/high-temperature cooling technologies. A schematic representation is presented in Fig. 1 of a community energy system incorporating TES and highlighting the various components of such an energy system.

The optimal integration of all of these technologies can be enhanced through the use of appropriate TES and often seasonal storage. But a better understanding is needed of optimal community-level seasonal storages, i.e., TESs that meet the needs of a group of buildings and that operate

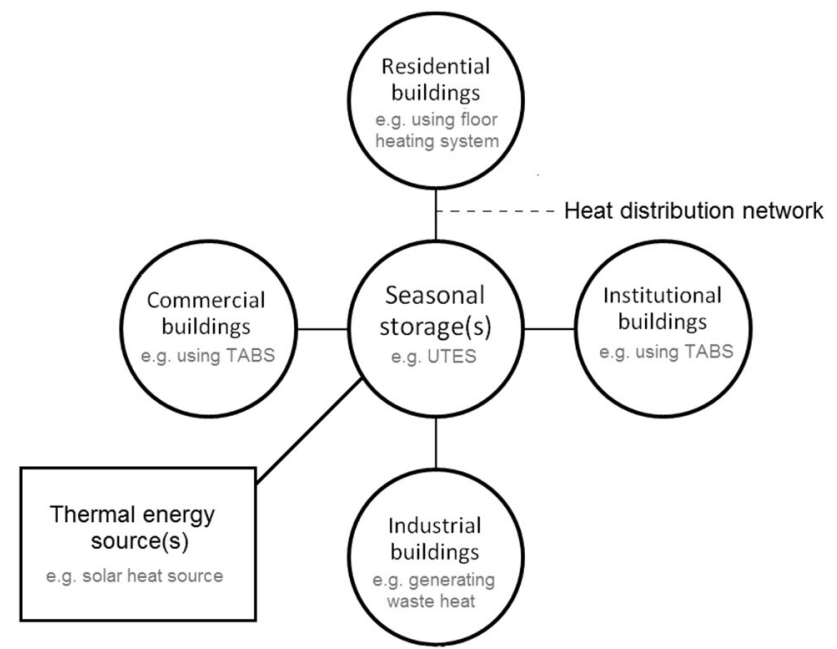

Fig. 1 Schematic of a community energy system incorporating TES and various types of buildings. Buildings are linked to one or more seasonal thermal energy storages (STES) and to each other via district energy grids over long time frames (seasonal or annual). This article aims to address that need in part and seeks to improve understanding of the characteristics of community-level TES. The main objective is to describe the status and needs relating to the optimal design of community seasonal energy storage.

\section{Community-level Seasonal Energy Storage: Status and Research}

Thermal storages that can be applied in various settings, including at the community level, have been investigated recently. For instance, an operating borehole thermal storage system for a solar community of several buildings has been examined ( $\mathrm{Rad}$ et al. 2017), as has a seasonal solar thermal storage that was converted into an innovative multifunctional storage (Schmidt and Mangold 2010). A research oriented book on thermal storage was recently published (Dincer and Rosen 2010), which covers many community-level applications.

Much research has been reported in recent years on systems for TES and enhancing their understanding. Relevant developments include improved modeling of thermal storage systems and predictions of their performance and operating characteristics. Also, efforts have been reported on the integration of thermal storages into buildings, their component parts and related energy systems (Guadalfajara et al. 2014). Relevant developments include enhanced modeling and design.

\subsection{Technologies}

Thermal energy storage methods, technologies and applications have been examined in detail [see chapter 9 of Dincer and Rosen (2010)] and several reviews published recently (Heier et al. 2015; Soares et al. 2013; Tatsidjodoung et al. 2013; Waqas and Din 2013). For example, advanced storage concepts for active solar energy being carried out through the IEA (Task 32) were recently reviewed (Hadorn 2008a), as were relevant applications with solar energy (Sharma et al. 2009; Singh et al. 2010). An overview has been presented of TES technologies and their status for solar heat (Hadorn 2008b). Reviews on solar TES in building heating and cooling supply are available (Lee 2010; Novo et al. 2010). The principal methods available for seasonal storage of solar thermal energy are provided by Pinel et al. (2011), concentrating on residential scale systems, particularly existing examples which mostly store energy in the form of sensible heat, and briefly discussing newer methods such as chemical and latent storage. A good example of systems utilizing TES in solar buildings is the Drake Landing Solar Community in Okotoks, 
Alberta, Canada, which incorporates a borehole seasonal storage to supply space heating to 52 detached energyefficient homes through a district heating network. The system and its operation are described by Sibbitt et al. (2012), and five-year performance data are presented.

Thermal storage systems that incorporate PCMs in the building envelope (e.g., in walls, floors, ceilings and windows), including basic principles, candidate PCMs and their thermophysical properties, incorporation methods and heat transfer enhancement, are also reviewed (Soares et al. 2013; Pomianowski et al. 2013; Navarro et al. 2016; Palomo del Barrio et al. 2017). A review on developments during the last four decades on seasonal TES in the ground, considering various storage concepts and natural and renewable energy sources, is provided by Pavlov and Olesen (2012) and new intelligent seasonal TES possibilities for use in combination with space heating, space cooling and domestic hot water systems are described.

Large seasonal heat storages for buildings often use storage mediums in the vicinity of the buildings as opposed to storage in the building structure. Some of these technologies include aquifer, borehole and snow storage as well as storage in pits or buried tanks. The state of the art and outlook for latent thermal storage in buildings have been presented (Heier et al. 2015; Soares et al. 2013). Seasonal heat storages in large basins like tanks and gravel-water pits have also been reviewed (Novo et al. 2010), as have phase change materials for thermal storage (Shukla et al. 2009; Agyenim et al. 2010; Kenisarim 2010; Desgrosseilliers et al. 2013). Applications of STES, often including communitylevel examples, have been reviewed in some regions and countries, e.g., Germany (Schmidt and Mangold 2008).

A summary of the articles reviewed in this section, indicating the focus as well as the energy storage mechanism and type used, is provided in Table 1.

\subsection{Concepts}

New concepts in thermal storage applicable in community settings have been proposed and examined, such as systems that integrate solar collectors and storage units (Kumar and Rosen 2010; Terziotti et al. 2012; Wang et al. 2012). Many researchers review TES technologies suitable for building applications, with a focus on storage materials and their classifications, recent developments, limitations and possible improvements for building uses (Tatsidjodoung et al. 2013; Cabeza et al. 2011). Investigations of thermal stratification, and the benefits it can provide in terms of efficiency and performance, have been reported (Njoku et al. 2014). Oil-pebble beds have been considered as thermal storages under various heat sources (Mawire and McPherson 2009). Furthermore, novel technologies have been investigated that may be included in practical systems, like binderless granulated molecular sieves (Jänchen et al. 2010). However, the use of chemical methods for seasonal storage has not yet progressed beyond small systems (Allegrini et al. 2015). Examinations have been published of novel solid-liquid micro-phase change materials for thermal storage in the form of microcapsules (Sari et al. 2010) and alternative phase change materials like calcium chloride hexahydrate (Tyagi and Buddhi 2008).

A summary is provided in Table 2 of the articles reviewed in this section, identifying the focus of the article as well as the energy storage mechanism and type considered.

\subsection{Performance}

The dynamic characteristics and energy performance of buildings using phase change materials have been reviewed (Zhu et al. 2009). Methods to improve the performance of thermal storages have also been investigated, including heat transfer improvement through the use of heat exchanger fins (Agyenim et al. 2009) and thermal conductivity enhancement (Alawadhi 2008), and the use of paraffin in a novel tube-in-shell thermal storage system (Akgün et al. 2008). Also, methods to determine stratification efficiency of TES processes have been reviewed and compared (Haller et al. 2009). Performance of thermal storage utilizing microcapsule phase change materials (Fang et al. 2010) and granular phase change composites (Rady et al. 2010) has also been examined, as have isothermal storage methods of solar energy for buildings (Heim 2010). Long-term test results have been reported from a latent heat storage for solar heating and cooling (Himpel et al. 2010). Also, the utilization of water phase transitions in seasonal thermal storage systems has been investigated (Eyem 2010).

A summary of the articles reviewed in this section, indicating the relevant performance topic as well as the energy storage mechanism and type, is provided in Table 3 .

\subsection{Size}

New concepts in compact thermochemical storage, likely to be applicable in community settings, have been proposed and examined (IEA 2010; van Essen et al. 2010; van Helden and Hauer 2010; Weber 2010; Heinz and Schranzhofer 2010), and the performance of this technology has been examined (Haji Abedin and Rosen 2010a), assessed (Rosen and Haji Abedin 2010) and reviewed (Haji Abedin and Rosen 2010b). A type of long-term thermochemical storage based on sorption processes has been reviewed (N'Tsoukpoe et al. 2009), while various sorption storages for solar thermal energy are reviewed (Yu et al. 2013). Advanced thermal storage materials have also been the focus of attention (Fernández et al. 2009; Ristic et al. 
Table 1 Summary of selected articles that mainly focus on thermal energy storage technologies

\begin{tabular}{|c|c|c|}
\hline Focus of study & References & Energy storage mechanism/system type \\
\hline Solar heating system for community & Rad et al. (2017) & Sensible/borehole \\
\hline Solar energy multifunctional storage & Schmidt and Mangold (2010) & \\
\hline Community-level applications & Dincer and Rosen (2010) & \\
\hline Building application; central solar heating plants & Guadalfajara et al. (2014) & Sensible/water tank \\
\hline $\begin{array}{l}\text { Thermal energy storage methods, technologies and } \\
\text { applications }\end{array}$ & Dincer and Rosen (2010) & \\
\hline Review article: building application & Heier et al. (2015) & \\
\hline Review article: building application & Soares et al. (2013) & Latent/PCM \\
\hline Review article: building application & Pomianowski et al. (2013) & Latent/PCM \\
\hline Review article: building application & Navarro et al. (2016) & Latent; sensible \\
\hline Review article & Palomo del Barrio et al. (2017) & Latent/PCM \\
\hline Solar energy systems & Hadorn $(2008 \mathrm{a}, \mathrm{b})$ & \\
\hline Review article & Lee $(2010)$ & Sensible/aquifer \\
\hline Review article & Novo et al. (2010) & $\begin{array}{l}\text { Sensible/water tank; Sensible/gravel-water } \\
\text { pit }\end{array}$ \\
\hline Review article: solar energy systems; building application & Pinel et al. (2011) & \\
\hline Solar energy systems; district energy & Sibbitt et al. (2012) & \\
\hline Review article: building application & Pavlov and Olesen (2012) & Sensible/UTES \\
\hline Solar water heater & Shukla et al. (2009) & Latent/PCM \\
\hline Review article & Agyenim et al. (2010) & Latent/PCM \\
\hline \multirow[t]{2}{*}{ Review article } & Kenisarim (2010) & Latent/high-temperature PCM \\
\hline & Desgrosseilliers et al. (2013) & Latent/PCM \\
\hline Community-level applications & Schmidt and Mangold (2008) & \\
\hline
\end{tabular}

Table 2 Summary of selected articles that introduce new concepts in thermal energy storage systems

\begin{tabular}{lll}
\hline Focus of study & References & Energy storage mechanism/system type \\
\hline Solar water heater & Kumar and Rosen (2010) & \\
Solar energy systems; building application & Terziotti et al. (2012) & Sensible/borehole \\
Solar energy systems; building application & Wang et al. (2012) & Latent/PCM \\
Review article & Cabeza et al. (2011) & \\
Review article: stratified thermal storage & Njoku et al. (2014) & Sensible/oil-pebble bed \\
& Mawire and McPherson (2009) & Thermochemical \\
Solar energy systems & Jänchen et al. (2010) & Latent/micro-PCM \\
Review article: district energy systems & Allegrini et al. (2015) & Latent/PCM \\
\hline
\end{tabular}

2010; Furbo et al. 2010), including composites (Hongois et al. 2010; Alkan et al. 2009).

A summary of the articles reviewed in this section showing the energy storage mechanism and type for compact thermal storages is provided in Table 4 .

\subsection{Cooling applications}

Special attention has been devoted in recent years to the use of thermal storage in conjunction with cooling systems
(Parameshwaran et al. 2010; Sanaye and Shirazi 2013; Waqas and Din 2013). For instance, high-temperature thermal storage has been considered for solar cooling applications (Gil et al. 2013), and specific integrations have been examined of long-term thermal storage for absorption cooling (N'Tsoukpoe et al. 2010).

Seasonal cold storage is also an efficient method of cooling which is reviewed widely (Yan et al. 2016; Veerakumar and Sreekumar 2016; Mastani Joybari et al. 2015). In this method, naturally or artificially produced cold 
Table 3 Summary of selected articles that analyze performance of thermal storage systems

\begin{tabular}{lll}
\hline Performance analysis topic & References & Energy storage mechanism/system type \\
\hline Use of phase change materials in buildings & Zhu et al. (2009) & Latent \\
Use of heat exchanger fins & Agyenim et al. (2009) & Latent \\
Thermal conductivity enhancement & Alawadhi (2008) & Sensible/water tank (cold storage) \\
Novel tube-in-shell design & Akgün et al. (2008) & Latent \\
Solar energy storage in stratified thermal storage systems & Haller et al. (2009) & \\
Use of microcapsule phase change material & Fang et al. (2010) & Latent \\
Use of granular phase changing composites & Rady et al. (2010) & Latent/granular phase change composites \\
Solar energy storage in building construction & Heim (2010) & Latent \\
Solar energy systems in buildings & Himpel et al. (2010) & Latent \\
Utilization of water phase transitions & Eyem (2010)s & Latent \\
\hline
\end{tabular}

Table 4 Summary of selected articles that focus on compact thermal energy storage systems

\begin{tabular}{ll}
\hline References & Energy storage mechanism/system type \\
\hline IEA (2010) & Latent/PCM; thermochemical \\
van Essen et al. (2010) & \\
Weber (2010) & Thermochemical \\
Heinz and Schranzhofer (2010) & Latent \\
Haji Abedin and Rosen (2010a) & Thermochemical \\
Rosen and Haji Abedin (2010) & Thermochemical \\
Haji Abedin and Rosen (2010b) & Thermochemical \\
N'Tsoukpoe et al. (2009) & Thermochemical \\
Yu et al. (2013) & Sorption \\
Fernández et al. (2009) & Sensible; latent \\
Ristic et al. (2010) & Sorption \\
Furbo et al. (2010) & Latent \\
Hongois et al. 2010 & Thermochemical \\
Alkan et al. (2009) & Latent
\end{tabular}

energy in winter (e.g., snow, ice, cold ambient air, frozen soil and rocks) is stored as ice in a tank and can be extracted as chilled water to meet building cooling needs in summer. Seasonal cold storage using heat pipes for cooling in buildings is investigated by Yan et al. (2016), but studies are limited in this area.

A summary of the articles reviewed in this section, specifying the cooling application we well as the energy storage mechanism and type, is provided in Table 5.

\subsection{Modeling, analysis and optimization}

Advanced activities have been reported and reviewed involving modeling, analysis and optimization related to thermal storage and applicable to community-level applications (Verma and Singal 2008; Tulus et al. 2016). Modeling is important for performance prediction and design of seasonal thermal energy stores due to their longterm effects (Allegrini et al. 2015). For instance, modeling activities using analytical and numerical techniques have been reported for a range of thermal storages, including underground hot water systems (Ochs et al. 2010), ground buried sand beds (Terziotti et al. 2012), borehole energy storage (Wang et al. 2012; Rad et al. 2013; Koohi-Fayegh and Rosen 2014; Cui et al. 2015; Eslami-nejad and Bernier 2013), aquifer thermal energy storage (Réveillèrea et al. 2013), cold storage (Yan et al. 2016; Alawadhi 2008), phase change thermal storage (Verma and Singal 2008; Dutil et al. 2014) and thermochemical storage (Kerskes et al. 2010). Models for seasonal storage in water tanks or gravel pits are available in some software tools such as TRNSYS (Dickinson et al. 2013). A hybrid solar groundsource heat pump system for heating and cooling of an office building (Wang et al. 2012) and a house (Rad et al. 2013) is also modeled in TRNSYS. Ground energy storage using boreholes is the most widely used method of seasonal energy storage. Models of ground heat exchangers and their applications are reviewed by Soni et al. (2015). Aquifer thermal energy storage systems use natural water in a saturated and permeable underground layer as the 
Table 5 Summary of articles selected that focus on cooling applications of thermal energy storage systems

\begin{tabular}{lll}
\hline Cooling application details & References & Energy storage mechanism/system type \\
\hline Building application & Parameshwaran et al. (2010) & Latent \\
Air-conditioning applications & Sanaye and Shirazi (2013) & Latent/ice storage \\
Building application; free cooling & Waqas and Din (2013) & Latent \\
Solar cooling & Gil et al. (2013) & Latent \\
Solar cooling & N'Tsoukpoe et al. (2010) & Thermochemical \\
Building application & Yan et al. (2016) & Latent/ice storage \\
& Veerakumar and Sreekumar (2016) & Latent \\
Building application & Mastani Joybari et al. (2015) & Latent \\
\hline
\end{tabular}

storage medium (Lee 2010). Information on the operating principles, design and construction of these systems can also be found (Lee 2010). Developments in using underground spaces for sensible heat storage are also described in several studies (Lee 2010; Novo et al. 2010). Alternatively, large water tanks and gravel-water pits can be used as storage media for sensible TES (Novo et al. 2010). Modeling and simulation to estimate ground energy storage long-term performance have been the focus of various studies (Wang et al. 2012; Koohi-Fayegh and Rosen 2014). However, they have significant modeling challenges regarding fast methods that can accurately calculate longterm behavior, particularly for multiple interacting boreholes (Allegrini et al. 2015; Koohi-Fayegh and Rosen 2014). Effects of parameters such as location and storage system design on a solar district heating system equipped with borehole seasonal storage have also been studied (Flynn and Siren 2015). Improvements to current ground storage systems such as use of PCMs in boreholes to improve ground heat pump efficiency and reduce the borehole design length are also examined (Eslami-nejad and Bernier 2013). Modeling ground thermal energy storage including aquifer storage is often performed using finite difference, element and volume methods using tools such as FEFLOW. Several models and software tools that address district-level interactions among energy systems including seasonal energy storage systems are reviewed in (Allegrini et al. 2015). Numerical models have been used to better understand thermal processes in the charging and discharging of the seasonal storages, such as hot water tanks in (Dickinson et al. 2013). When using multiple storages, various charging and discharging strategies such as charging and discharging of storages in parallel or series or their combination are studied (Dickinson et al. 2013). Since results of analytical and numerical modeling can be strongly dependent on assumed storage characteristics (i.e., material) for some storage types, field scale living laboratories have also been built in some cases [e.g., in Torino, Italy (Giordano et al. 2016)] to calibrate the results on real data.
Numerical approaches have also been developed for forecasting thermal energy storage performance (Varol et al. 2010). Also, efficiency measures based on energy and exergy have been proposed and applied for various TESs (Rosen 2011; Dincer and Rosen 2012; Rezaie et al. 2015; Li 2016), including cold storage (Rosen and Dincer 2009). The main methods have been reviewed for modeling and assessing performance of stratified thermal storage (Njoku et al. 2014). Further, techno-economic assessments of heat and cold thermal storage systems have been applied, often using advanced methods like exergoeconomics (economics based on exergy) (Rosen 2011; Mosaffa and Garousi Farshi 2016). The economics of thermal storage systems in conjunction with cogeneration, trigeneration and DE have also been the subject of numerous investigations (Rentizelas et al. 2009; Lozano et al. 2009a, 2010; Balli et al. 2010; Dominković et al. 2015), including thermoeconomic analyses (Balli et al. 2010) and economic optimization of designs (Lozano et al. 2010).

Appropriate thermal storage utilization can also support the concept of "zero peak communities," which are communities or subdivisions that do not contribute to the utility system peak (Christian et al. 2007), providing a powerful tool in demand-side management programs (Arteconi et al. 2012). By reducing peak loads, such communities can assist electric utilities in providing affordable and reliable electric power and in enhancing environmental stewardship and sustainable development. Community-level seasonal storage can also facilitate the development of "net-zero energy buildings" (NZEB) and communities, with net-zero average annual energy consumption at both the building and neighborhood levels, and yield efficiency, economic and environmental benefits. Much research is currently being carried out on energy design and operation concepts to drive them toward such targets. These include applications, field trials and concepts of innovative systems that will improve energy efficiency and integration of renewable technologies in buildings. For example, much research effort by the Smart Net-Zero Energy Building Research Network (SNEBRN) in Canada (SNEBRN 2015) is 
dedicated to developing concepts and designs in a combination of systems and technologies, including short-term and seasonal thermal storage (Desgrosseilliers et al. 2013; Wang et al. 2012; Rad et al. 2013; Koohi-Fayegh and Rosen 2014; Eslami-nejad and Bernier 2013; Dickinson et al. 2013) along with heat pump systems, combined heat and power technologies, integrated solar systems, highperformance windows and smart controls, that are suited to Canadian climatic conditions and construction practices to design smart net-zero energy buildings and to influence long-term national policies on their future development.

Optimization methods have also been applied to airconditioning using ice storage (Sanaye and Shirazi 2013) and stratified thermal storages (Schütz et al. 2015; Jack and Wrobel 2009) and to operating modes for seasonal underground thermal storages (Zhao et al. 2008). Finally, systems that integrate different types of thermal storage, with the aim of maximizing the advantages of each, have been proposed and investigated (Weber et al. 2010).

\subsection{Sustainability}

More broadly, the role of thermal storage for sustainable buildings has been examined (Heier et al. 2015; Rad et al. 2017; Dincer and Rosen 2008; Orehounig et al. 2014). A critical review of the integration of thermal storage and HVAC systems has been published, along with recent advances (Haji Abedin and Rosen 2010c). Performance analyses of building energy systems (Soares et al. 2013; Arkar et al. 2016) and HVAC equipment (Parameshwaran et al. 2010; Kanoglu et al. 2007) have also been reported, often using advanced analysis methods. Performance enhancements have been described of subcooled cold storage integrated with air-conditioning (Hsiao et al. 2009). Models of geothermal heat pumps with vertical ground interfaces have been presented for use in HVAC systems (Kouhi-Fayegh and Rosen 2010). Also, sustainability assessments of community systems, incorporating case studies and simulations, have been recently carried out considering exergy and environmental factors (Solberg 2010). Furthermore, improving the sustainability and environmental performance of energy systems, through the utilization of thermal storage in conjunction with cogeneration, trigeneration and $\mathrm{DE}$, has been the motivation behind much research focusing on environmental emissions and impacts such as climate change (Rentizelas et al. 2009; Balli et al. 2010).

\subsection{Integration with energy systems}

Modeling and optimization methods have been developed and employed for a wide range of district energy (DE), cogeneration and trigeneration systems (Réveillèrea et al.
2013; (Dominković et al. 2015; Lozano et al. 2009b; Erdem et al. 2010; Wang et al. 2015; Mago et al. 2009; Mancarella 2014), which often are integral to community energy systems. Included in many of these studies are examinations of the most advantageous role of energy storage (Rong et al. 2008) and advances in that technology (Lund et al. 2014), as well as specialized integrated applications (Chacartegui et al. 2009; Lai and Hui 2010). This includes determining for such systems the most viable and optimal scale (Wang et al. 2015; Chicco and Mancarella 2009a; Badami and Portoraro 2009; Kavvadias et al. 2010), the required level of flexibility (Lai and Hui 2009) and appropriate operation strategies (Kavvadias et al. 2010). Also, optimization methods have been applied to the operation and structure of cogenerationbased district heating with long-term thermal storage (Tveit et al. 2009). Many recent studies have focused on alternative and sustainable energy sources, including biomass (Rentizelas et al. 2009; Dominković et al. 2015), while others have focused on the development of improved technologies for waste heat recovery (Cui et al. 2015) and trigeneration and DE (IEA 2009) considering diesel engines (Balli et al. 2010), micro-gas turbines with steam ejector refrigeration (Ameri et al. 2010), advanced heat pumps (Mancarella 2009), fuel cells (Al-Sulaiman et al. 2010; Malico et al. 2009), liquid desiccant cooling systems (Badami and Portoraro 2009) and distributed multi-generation (Chicco and Mancarella 2009b). The significant knowledge gaps for integrating optimally thermal storage with cogeneration, trigeneration and DE, and the need to use exergy in such research, have been recognized by the International Energy Agency, which over the last decade has commissioned several annexes to investigate and implement systems incorporating cogeneration, trigeneration, district heating and cooling, and thermal storage (Lozano et al. 2010; IEA 2009). For instance, a guidebook on low-exergy systems for highperformance buildings and communities was recently released (IEA 2010).

\section{Needs and Priorities in System Research and Design}

The use of community-level seasonal storage has not received a great deal of attention in the past, but has become increasingly of interest in recent years. The appropriate utilization of community-level thermal storage can yield benefits in terms of efficiency, economics, environmental impact, etc. But many issues exist that need to be resolved to allow optimal solutions to be attained. In this section, general needs and priority areas are identified and described. 


\subsection{General needs}

Numerous needs exist in a variety of areas related to STES for community-level applications:

- Single versus multiple storage. The scale and number of thermal storages in a community need to be better assessed. Some efforts have focused on single storages scaled to a size appropriate for a given community, while others have focused on multiple smaller storages appropriately located throughout the community. Although smaller storages tend to have higher thermal energy losses due to higher surface area to volume ratios, other efficiency advantages of multiple storages in community settings can make the decision to develop multiple storages advantageous.

- Short-term versus midterm versus long-term storage. The appropriate time duration capacities of thermal storages in a community need to be determined. Longterm storage (based on seasonal or annual storage cycles) is preferred for some community energy systems, while short-term (diurnal) and midterm (weekly) thermal storages are appropriate for other community applications. Sometimes, a combination of short-, medium- and long-term storage is required to yield the most benefits from community energy systems. This is observed at some existing community energy systems. For example, the Drake Landing Solar Community in Okotoks, Alberta, uses a combination of seasonal ground-based storage with short-term liquid storage tanks.

- Sensible versus latent energy storage. The type of thermal storage(s) in a community energy system needs to be better analyzed and identified. Some systems benefit from utilizing sensible storages, while others benefit from the use of latent or thermochemical storages. There are also systems that may benefit from using a combination of these types. Although the combined use of thermal energy storage types has proved to be beneficial compared to single-type use in some cases [e.g., tank/PCM in a concentrating solar collector system (Bhale et al. 2015) or packed bed/PCM (Geissbühler et al. 2016; Zavattoni et al. 2015)], few studies are reported in the literature on the combined use of sensible and latent thermal storage systems. Moreover, there is a need for studies that focus on optimization of combined use of these storage types for various energy systems and energy storage needs.

- Developments are needed in seasonal storage technology and systems themselves, in terms of factors such as efficiency, reliability, economics, environmental impact and others, so as to achieve optimal performance of community energy system applications.
- Research is needed to quantify the most appropriate TES parameters for the optimal integration of thermal energy users (buildings), thermal energy suppliers and thermal grids. The potential ways are numerous to use of TES in such an integrated set of energy suppliers and users.

- Storage system integration with communities. Improved understanding of the appropriate integration of thermal storage into communities having numerous buildings is needed, particularly where renewable energy sources (e.g., solar) and advanced energy technologies are utilized, as such systems are extremely complex.

- Advanced methods and tools. Developments of advanced tools are required for modeling, simulation, analysis, improvement, design and optimization. Incorporation of advanced methods like exergy analysis for analysis, improvement and optimization has been recognized as important, but are at present only sparingly used.

\subsection{Priority needs}

Priority needs for development and research fall into four main areas, which are identified and described in this section.

\subsubsection{Development of new and enhancement of existing community-level seasonal TESs}

There is a need to develop seasonal storage technology and systems, in order to enhance their efficiency, reliability, economics and environmental impact, and to achieve optimal performance in community energy system applications. Determination of new concepts, and the appropriate scale and number of thermal storages, time duration capacities (long-, mid- and short-term) and storage types (sensible, latent, thermochemical) is also needed for community-level seasonal storage in varied settings.

\subsubsection{Development of new configurations for community- level seasonal storage}

There is a need for new configurations for community-level seasonal storage, taking into account the storage and the community in which it is located and operates. Development of such configurations is dependent not only on the community-level seasonal storage system type, but also on both the nature and characteristics of the community and its buildings (e.g., industrial, commercial and residential) (Heier et al. 2015; Flynn and Siren 2015) as well as type of energy supplies available (e.g., conventional, renewable and waste recovery). 


\subsubsection{Enhancement of the integration of seasonal TES into communities and their buildings}

The integration of STES storage schemes into communities and their buildings needs to be enhanced. This requires quantification of the most appropriate thermal storage parameters for the optimal integration of thermal energy users (i.e., buildings), thermal energy suppliers and thermal grids/networks. This need also encompasses improvement in understanding of the appropriate integration of thermal storage into communities that have numerous buildings for a wide range of energy technologies.

\subsubsection{Development of appropriate tools for modeling, simulation, analysis, improvement, design and optimization}

Appropriate tools for the above tasks need to be developed, and existing tools need to be enhanced and/or extended, while ensuring that they enable appropriate modeling, simulation, analysis, improvement, design and optimization of community-level seasonal storage. Several tools have already been proposed or reviewed for the evaluation and design of integrated energy components including seasonal energy storage and energy supplies for the community (Guadalfajara et al. 2014; Orehounig et al. 2014). The tools are expected to have at least three main capabilities:

- Modeling and simulation. Improved seasonal thermal storage models will be developed to assist predictions of performance and behavior of seasonal thermal storage in the context of overall community energy systems. The aim will be to better predict the behaviors of thermal storages when integrated into complex systems and, as a consequence, better predict the performance and behavior of the broader community energy systems. For instance, ground-based thermal storages are proving increasingly advantageous for seasonal applications, leading to a significant need to develop advanced methods for predicting ground heat transfer for a wide range of in-ground technology, systems and applications.

- Analysis and design. Advanced methods will be developed for improving understanding of the efficiencies and losses for seasonal energy storage systems and community systems that incorporate them. Exergy methods will be utilized to understand not only the quantitative flows of thermal energy, but also of their qualities. Furthermore, these methods will be applied to improve designs and configurations of seasonal thermal storages for community applications.

- Optimization and improvement. Research will be undertaken to ascertain the most appropriate seasonal thermal storage systems for community applications, as well as for the most advantageous integration of the storage systems into communities. Factors such as efficiency, economics and environmental impact will be considered. It is pointed out that environmental impact will be examined from two perspectives: the environmental benefits achieved through the use of the thermal storage systems as well as the environmental impacts caused by implementing such storages (e.g., the impact on ecosystems of heat flows away from an underground storage). Appropriate optimization schemes will be developed and applied.

In addition, it would be helpful for models to consider not just deterministic effects, but also stochastic factors. Accounting for the impact of stochastic elements on TES modeling and optimization would help improve their accuracy and realism. Some work has been done in this field. For instance, the stochastic control of thermal storage-enabled demand response from flexible district energy systems has been investigated (Kitapbayev et al. 2015), as has the stochastic risk-averse coordinated scheduling of grid integrated energy storage units in transmission constrained wind-thermal systems (Hemmati et al. 2016).

\section{Expected Outcomes from Addressing Needs}

If the needs identified in the previous section are addressed, several significant and important outcomes are likely to accrue:

- Improved and/or optimal thermal storage technology and systems for community-level seasonal storage, in terms of efficiency, reliability, economics and environmental impact, and for a variety of settings.

- Improved configurations for community-level seasonal storage that account for community and building characteristics as well as available energy supplies.

- Enhanced schemes for integrating seasonal storage into communities and their buildings, for a wide range of technology and settings.

- Enhanced tools for modeling, simulation, analysis, improvement, design and optimization, for communitylevel seasonal storage.

\section{Conclusions}

The status of community-level seasonal storage suggests that the technology is working, but that room exists to optimize such systems. Many needs exist to support such optimization. If these needs are addressed, several 
significant and important outcomes are likely to accrue, which will facilitate better building and community energy systems. These outcomes will be achieved by enhanced thermal storage technology and systems for communitylevel applications, improved configurations for community-level seasonal storage, and better integration of seasonal storage into communities and their buildings.

Acknowledgements Support provided by the Natural Sciences and Engineering Research Council of Canada is gratefully acknowledged.

\section{References}

Agyenim F, Eames P, Smyth M (2009) A comparison of heat transfer enhancement in a medium temperature thermal energy storage heat exchanger using fins. Sol Energy 83:1509-1520

Agyenim F, Hewitt N, Eames P, Smyth M (2010) A review of materials, heat transfer and phase change problem formulation for latent heat thermal energy storage systems (LHTESS). Renew Sust Energy Rev 14:615-628

Akgün M, Aydın O, Kaygusuz K (2008) Thermal energy performance of paraffin in a novel tube-in-shell system. Appl Therm Eng 28:405-413

Alawadhi EM (2008) Numerical analysis of a cool-thermal storage system with a thermal conductivity enhancer operating under a freezing condition. Energy 33:796-803

Alkan C, Kaya K, Sari A (2009) Preparation, thermal properties and thermal reliability of form-stable paraffin/polypropylene composite for thermal energy storage. J Polym Environ 17:254-258

Allegrini J, Orehounig K, Mavromatidis G, Ruesch F, Dorer V, Evins $\mathrm{R}$ (2015) A review of modelling approaches and tools for the simulation of district-scale energy systems. Renew Sust Energy Rev 52:1391-1404

Al-Sulaiman FA, Dincer I, Hamdullahpur F (2010) Energy analysis of a trigeneration plant based on solid oxide fuel cell and organic Rankine cycle. Int J Hydrog Energy 35:5104-5113

Ameri M, Behbahaninia A, Tanha AA (2010) Thermodynamic analysis of a tri-generation system based on micro-gas turbine with a steam ejector refrigeration system. Energy 35:2203-2209

Arkar C, Šuklje T, Vidrih B, Medved S (2016) Performance analysis of a solar air heating system with latent heat storage in a lightweight building. Appl Therm Eng 95:281-287

Arteconi A, Hewitt NJ, Polonara F (2012) State of the art of thermal storage for demand-side management. Appl Energy 93:371-389

Badami M, Portoraro A (2009) Performance analysis of an innovative small-scale trigeneration plant with liquid desiccant cooling system. Energy Build 41:1195-1204

Balli O, Aras H, Hepbasli A (2010) Thermodynamic and thermoeconomic analyses of a trigeneration (TRIGEN) system with a gas-diesel engine: parts I and II. Energy Convers Manag 51:2252-2271

Bhale PV, Rathod MK, Sahoo L (2015) Thermal analysis of a solar concentrating system integrated with sensible and latent heat storage. Energy Proc 75:2157-2162

Cabeza LF, Castell A, Barreneche C, de Gracia A, Fernández AI (2011) Materials used as PCM in thermal energy storage in buildings: a review. Renew Sust Energy Rev 15(3):1675-1695

Chacartegui R, Sánchez D, di Gregorio N, Jiménez-Espadafor FJ, Muñoz A, Sánchez T (2009) Feasibility analysis of a MED desalination plant in a combined cycle based cogeneration facility. Appl Therm Eng 29:412-417
Chicco G, Mancarella P (2009a) Matrix modeling of small-scale trigeneration systems and application to operational optimization. Energy 34:261-273

Chicco G, Mancarella P (2009b) Distributed multi-generation: a comprehensive view. Renew Sust Energy Rev 13:535-551

Christian J, Pratsch L, Blasing TJ (2007) Zero peak communities electric utility benefits. In: Thermal performance of the exterior envelopes of buildings X: proceedings of ASHRAE THERM X, Clearwater, FL, 2-7 Dec 2007, pp 1-7

Cui P, Diao N, Gao C, Fang Z (2015) Thermal investigation of inseries vertical ground heat exchangers for industrial waste heat storage. Geothermics 57:205-212

Desgrosseilliers L, Whitman CA, Groulx D, White MA (2013) Dodecanoic acid as a promising phase-change material for thermal energy storage. Appl Thermal Eng 53:37-41

Dickinson RM, Cruickshank CA, Harrison SJ (2013) Charge and discharge strategies for a multi-tank thermal energy storage. Appl Energy 109:366-373

Dincer I, Rosen MA (2008) Exergetically efficient thermal energy storage systems for sustainable buildings. ASHRAE Trans 114(1):98-107

Dincer I, Rosen MA (2010) Thermal energy storage systems and applications, 2nd edn. Wiley, London

Dincer I, Rosen MA (2012) Exergy: energy, environment and sustainable development, 2nd edn. Elsevier, Oxford

Dominković DF, Ćosić B, Bačelić Medić Z, Duić N (2015) A hybrid optimization model of biomass trigeneration system combined with pit thermal energy storage. Energy Convers Manag 104:90-99

Dutil Y, Rousse D, Lassue S, Zalewski L, Joulin A, Virgone J, Kuznik F, Johannes K, Dumas JP, Bédécarrats JP, Castell A, Cabeza LF (2014) Modeling phase change materials behavior in building applications: comments on material characterization and model validation. Renew Energy 61:132-135

Erdem HH, Dagdas A, Sevilgen SH, Cetin B, Akkaya AV, Sahin B, Teke I, Gungor C, Atas S (2010) Thermodynamic analysis of an existing coal-fired power plant for district heating/cooling application. Appl Therm Eng 30:81-187

Eslami-nejad P, Bernier M (2013) A preliminary assessment on the use of phase change materials around geothermal boreholes. ASHRAE Trans 119(2):312-321

Eyem J (2010) Utilizing of water phase transitions in seasonal heat storage systems. In: Proceedings of EuroSun 2010: international conference on solar heating, cooling and buildings, Graz, Austria, 28 Sept-1 Oct, 2010, paper 201

Fang G, Li H, Liu X, Wu S (2010) Experimental investigation of performances of microcapsule phase change material for thermal energy storage. Chem Eng Technol 33:227-230

Fernández AI, Martínez M, Segarra M, Cabeza LF (2009) Selection of materials with potential in thermal energy storage. In: Proceedings of Effstock 2009: thermal energy storage for efficiency and sustainability, Stockholm, Sweden

Flynn C, Siren K (2015) Influence of location and design on the performance of a solar district heating system equipped with borehole seasonal storage. Renew Energy 81:377-388

Furbo S, Dragsted J, Chen Z, Fan J, Andersen E, Perers B (2010) Towards seasonal heat storage based on stable super cooling of sodium acetate trihydrate. In: Proceedings of EuroSun 2010: international conference on solar heating, cooling and buildings, Graz, Austria, 28 Sept-1 Oct, 2010, paper 269

Geissbühler L, Kolman M, Zanganeh G, Haselbacher A, Steinfeld A (2016) Analysis of industrial-scale high-temperature combined sensible/latent thermal energy storage. Appl Therm Eng 101:657-668 
Gil A, Oró E, Castell A, Cabeza LF (2013) Experimental analysis of the effectiveness of a high temperature thermal storage tank for solar cooling applications. Appl Therm Eng 54(2):521-527

Giordano N, Comina C, Mandrone G, Cagni A (2016) Borehole thermal energy storage (BTES). First results from the injection phase of a living lab in Torino (NW Italy). Renew Energy 86:993-1008

Guadalfajara M, Miguel A, Lozano L, Serra L (2014) Comparison of simple methods for the design of central solar heating plants with seasonal storage. Energy Proc 48:11107-11115

Hadorn JC (2008a) Advanced storage concepts for active solar energy: IEA-SHC Task 32 2003-2007. In: Proceedings of Eurosun 2008: 1st international conference on solar heating, cooling and buildings, Lisbon, Portugal, 7-10 October 2008, paper 009

Hadorn JC (2008b) Thermal energy storage: overview of technologies and status for solar heat. In: Proceedings of Eurosun 2008: 1st international conference on solar heating, cooling and buildings, Lisbon, Portugal, 7-10 October 2008

Haji Abedin A, Rosen MA (2010a) Energy and exergy analysis of a closed thermochemical energy storage system. In: Proceedings of 5th international green energy conf, 1-3 June, Waterloo, Ontario, pp 1-9

Haji Abedin A, Rosen MA (2010b) Thermochemical energy storage: critical review and recent advances. In: Proceedings of 5th international green energy conference, 1-3 June, Waterloo, Ontario, pp 1-7

Haji Abedin A, Rosen MA (2010c) Integrating thermal energy storage and HVAC systems: critical review and recent advances. In: Proceedings of Canadian Society for Mechanical Engineering Forum 2010, 7-9 June, Victoria, British Columbia, paper 8, pp 1-8

Haller MY, Cruickshank CA, Streicher W, Harrison SJ, Andersen E, Furbo S (2009) Methods to determine stratification efficiency of thermal energy storage processes-review and theoretical comparison. Sol Energy 83:1847-1860

Heier J, Bales C, Martin V (2015) Combining thermal energy storage with buildings-a review. Renew Sust Energy Rev 42:1305-1325

Heim D (2010) Isothermal storage of solar energy in building construction. Renew Energy 35:788-796

Heinz A, Schranzhofer H (2010) Thermal energy storage with phase change materials-a promising solution? In: Proceedings of: EuroSun 2010: international conference on solar heating, cooling and buildings, Graz, Austria, 28 Sept-1 Oct, 2010, paper 206

Hemmati R, Saboori H, Saboori S (2016) Stochastic risk-averse coordinated scheduling of grid integrated energy storage units in transmission constrained wind-thermal systems within a conditional value-at-risk framework. Energy 113:762-775

Himpel M, Hiebler S, Helm M, Schweigler C (2010) Long term test results from a latent heat storage developed for a solar heating and cooling system. In: Proceedings of EuroSun 2010: international conference on solar heating, cooling and buildings, Graz, Austria, 28 Sept-1 Oct, 2010, paper 207

Hongois S, Kuznik F, Stevens P, Roux JJ, Radulescu M, Beaurepaire E (2010) Thermochemical storage using composite materials: from the material to the system. In: Proceedings of EuroSun 2010: international conference on solar heating, cooling and buildings, Graz, Austria, 28 Sept-1 Oct, 2010, paper 209

Hsiao M, Cheng C, Huang M, Chen S (2009) Performance enhancement of a subcooled cold storage air conditioning system. Energy Convers Manag 50:2992-2998

International Energy Agency (IEA) (2009) Cogeneration and district energy: Sustainable energy technologies for today and tomorrow, Paris

International Energy Agency (IEA) (2010) Low exergy systems for high-performance buildings and communities, guidebook, energy conservation in buildings and community systems, Annex 49

International Energy Agency (IEA), Task 42, Compact thermal energy storage-material development and system integration. http://task42.iea-shc.org/. Jan 2017

Jack MW, Wrobel J (2009) Thermodynamic optimization of a stratified thermal storage device. Appl Therm Eng 29:2344-2349

Jänchen J, Brandt A, Schmeißer J, Unger B, Stach H, Hellwig U (2010) Novel binderless granulated molecular sieves for thermochemical heat storage. In: Proceedings of EuroSun 2010: international conference on solar heating, cooling and buildings, Graz, Austria, 28 Sept-1 Oct, 2010, paper 211

Kanoglu M, Dincer I, Rosen MA (2007) Exergy analysis of psychrometric processes for HVAC\&R applications. ASHRAE Trans 113(Part 2):172-180

Kavvadias KC, Tosios AP, Maroulis ZB (2010) Design of a combined heating, cooling and power system: sizing, operation strategy selection and parametric analysis. Energy Convers Manag 51:833-845

Kenisarim MM (2010) High-temperature phase change materials for thermal energy storage. Renew Sust Energy Rev 14:955-970

Kerskes H, Mette B, Asenbeck S, Drück H, Müller-Steinhagen H (2010) Experimental and numerical investigations on thermochemical heat storage. In: Proceedings of EuroSun 2010: international conference on solar heating, cooling and buildings, Graz, Austria, 28 Sept-1 Oct, 2010, paper 213

Kitapbayev Y, Moriarty J, Mancarella P (2015) Stochastic control and real options valuation of thermal storage-enabled demand response from flexible district energy systems. Appl Energy 137:823-831

Koohi-Fayegh S, Rosen MA (2014) An analytical approach to evaluating the effect of thermal interaction of geothermal heat exchangers on ground heat pump efficiency. Energy Convers Manag 78:184-192

Kouhi-Fayegh S, Rosen MA (2010) The modeling of geothermal heat pumps with vertical ground interfaces for use in HVAC systems. In: Proceedings of 5th international green energy conference, 1-3 June, Waterloo, Ontario, pp 1-12

Kumar R, Rosen MA (2010) Thermal performance of integrated collector storage solar water heater with corrugated absorber surface. Appl Therm Eng 30(13):1764-1768

Lai SM, Hui CW (2009) Feasibility and flexibility for a trigeneration system. Energy 34:1693-1704

Lai SM, Hui CW (2010) Integration of trigeneration system and thermal storage under demand uncertainties. Appl Energy 87(9):2868-2880

Lee KS (2010) A review on concepts, applications, and models of aquifer thermal energy storage systems. Energies 3(6):1320 1334

Li G (2016) Sensible heat thermal storage energy and exergy performance evaluations. Renew Sust Energ Rev 53:897-923

Lozano MA, Carvalho M, Ramos JC, Serra LM (2009a) Thermoeconomic analysis of simple trigeneration systems. Int $\mathrm{J}$ Thermodyn 12:147-153

Lozano MA, Ramos JC, Carvalho M, Serra LM (2009b) Structure optimization of energy supply systems in tertiary sector buildings. Energy Build 41:1063-1075

Lozano MA, Ramos JC, Serra LM (2010) Cost optimization of the design of CHCP (combined heat, cooling and power) systems under legal constraints. Energy 35:794-805

Lund H, Werner S, Wiltshire R, Svendsen S, Thorsen JE, Hvelplund F, Vad Mathiesen B (2014) 4th Generation District Heating (4GDH): integrating smart thermal grids into future sustainable energy systems. Energy 68:1-11

Mago PJ, Chamra LM, Hueffed A (2009) A review on energy, economical, and environmental benefits of the use of CHP 
systems for small commercial buildings for the North American climate. Int J Energy Res 33:1252-1265

Malico I, Carvalhinho AP, Tenreiro J (2009) Design of a trigeneration system using a high-temperature fuel cell. Int J Energy Res 33:144-151

Mancarella P (2009) Cogeneration systems with electric heat pumps: energy-shifting properties and equivalent plant modeling. Energy Convers Manag 50:1991-1999

Mancarella P (2014) MES (multi-energy systems): an overview of concepts and evaluation models. Energy 65:1-17

Mastani Joybari M, Haghighat F, Moffat J, Sra P (2015) Heat and cold storage using phase change materials in domestic refrigeration systems: the state-of-the-art review. Energy Build 106:111-124

Mawire A, McPherson M (2009) Experimental and simulated temperature distribution of an oil-pebble bed thermal energy storage system with a variable heat source. Appl Therm Eng 29:1086-1095

Mosaffa AH, Garousi Farshi L (2016) Exergoeconomic and environmental analyses of an air conditioning system using thermal energy storage. Appl Energy 162:515-526

N'Tsoukpoe KE, Le Pierrès N, Luo L (2010) Theoretical investigation of a long-term solar energy storage based on $\mathrm{LiBr} / \mathrm{H}_{2} \mathrm{O}$ absorption cycle. In: Proceedings of EuroSun 2010: international conference on solar heating, cooling and buildings, Graz, Austria, 28 Sept-1 Oct, 2010, paper 222

Navarro L, de Gracia A, Colclough S, Browne M, McCormack SJ, Griffiths P, Cabeza LF (2016) Thermal energy storage in building integrated thermal systems: a review. Part 1. Active storage systems. Renew Energy 88:526-547

Njoku HO, Ekechukwu OV, Onyegegbu SO (2014) Analysis of stratified thermal storage systems: an overview. Heat Mass Transf 50:1017-1030

Novo AV, Bayon JR, Castro-Fresno D, Rodriguez-Hernandez J (2010) Review of seasonal heat storage in large basins: water tanks and gravel-water pits. Appl Energy 87:390-397

N'Tsoukpoe KE, Liu H, Le Pierrès N, Luo L (2009) A review on long-term sorption solar energy storage. Renew Sust Energy Rev 13:2385-2396

Ochs F, Heidemann W, Müller-Steinhagen H (2010) Modeling buried hot water thermal energy stores. In: Proceedings of EuroSun 2010: international conference on solar heating, cooling and buildings, Graz, Austria, 28 Sept-1 Oct, 2010, paper 223

Orehounig K, Mavromatidis G, Evins R, Dorer V, Carmeliet J (2014) Towards an energy sustainable community: an energy system analysis for a village in Switzerland. Energy Build 84:277-286

Palomo del Barrio E, Godin A, Duquesne M, Daranlot J, Jolly J, Alshaer W, Kouadio T, Sommier A (2017) Characterization of different sugar alcohols as phase change materials for thermal energy storage applications. Sol Energy Mater Sol C 159:560-569

Parameshwaran R, Harikrishnan S, Kalaiselvam S (2010) Energy efficient PCM-based variable air volume air conditioning system for modern buildings. Energy Build 42(8):1353-1360

Pavlov GK, Olesen BW (2012) Thermal energy storage-a review of concepts and systems for heating and cooling applications in buildings: Part 1 -seasonal storage in the ground. HVAC\&R Res 18(3):515-538

Pinel P, Cruickshank CA, Beausoleil-Morrison I, Wills A (2011) A review of available methods for seasonal storage of solar thermal energy in residential applications. Renew Sust Energy Rev $15: 3341-3359$

Pomianowski M, Heiselberg P, Zhang Y (2013) Review of thermal energy storage technologies based on PCM application in buildings. Energy Build 67:56-69

Rad FM, Fung AS, Leong WH (2013) Feasibility of combined solar thermal and ground source heat pump systems in cold climate, Canada. Energy Build 61:224-232
Rad FM, Fung AS, Rosen MA (2017) An integrated model for designing a solar community heating system with borehole thermal storage. Energy Sustain Dev 36:6-15

Rady MA, Arquis E, Le Bot C (2010) Characterization of granular phase changing composites for thermal energy storage using the T-history method. Int J Energy Res 34:333-344

Rentizelas A, Tolis A, Tatsiopoulos I (2009) Biomass district energy trigeneration systems: emissions reduction and financial impact. Water Air Soil Pollut Focus 9:139-150

Réveillèrea A, Hamma V, Lesueur H, Cordier E, Goblet P (2013) Geothermal contribution to the energy mix of a heating network when using Aquifer Thermal Energy Storage: modeling and application to the Paris basin. Geothermics 47:69-79

Rezaie B, Reddy BV, Rosen MA (2015) Exergy analysis of thermal energy storage in a district energy application. Renew Energy 74:848-854

Ristic A, Henninger SK, Zabukovec Logar N, Kaucic V (2010) Novel adsorption material for thermal energy storage. In: Proceedings of EuroSun 2010: international conference on solar heating, cooling and buildings, Graz, Austria, 28 Sept-1 Oct, 2010, paper 226

Rong A, Lahdelma R, Luh PB (2008) Lagrangian relaxation based algorithm for trigeneration planning with storages. Eur J Oper Res 188:240-257

Rosen MA (2011) Economics and exergy: an enhanced approach to energy economics. Nova Science Publishers, Hauppauge

Rosen MA, Dincer I (2009) Efficiency assessment of glycol cold thermal energy storage and effect of varying environment temperature. Trans Can Soc Mech Eng 33(1):119-130

Rosen MA, Haji Abedin A (2010) Energy and exergy analyses of a closed thermochemical energy storage system: methodology and illustrative application. In: Proceedings of 23rd international conference on efficiency, cost, optimization, simulation and environmental impact of energy systems, 14-17 June 2010, Lausanne, Switzerland, pp 1-8

Sanaye S, Shirazi A (2013) Thermo-economic optimization of an ice thermal energy storage system for air-conditioning applications. Energy Build 60:100-109

Sari A, Alkan C, Karaipekli A (2010) Preparation, characterization and thermal properties of PMMA/n-heptadecane microcapsules as novel solid-liquid microPCM for thermal energy storage. Appl Energy 87:1529-1534

Schmidt T, Mangold D (2008) Seasonal thermal energy storage in Germany. In: Proceedings of Eurosun 2008: 1st international conference on solar heating, cooling and buildings, Lisbon, Portugal, 7-10 Oct 2008, paper 225

Schmidt T, Mangold D (2010) Conversion of Germany's first seasonal solar thermal energy storage into an innovative multifunctional storage. In: Proceedings of EuroSun 2010: international conference on solar heating, cooling and buildings, Graz, Austria, 28 Sept-1 Oct, 2010, paper 227

Sharma A, Tyagi V, Chen C, Buddhi D (2009) Review on thermal energy storage in phase change materials and applications. Renew Sust Energy Rev 13:318-345

Shukla A, Buddhi D, Sawhney RL (2009) Solar water heaters with phase change material thermal energy storage medium: a review. Renew Sust Energy Rev 13:2119-2125

Sibbitt B, McClenahan D, Djebbar R, Thornton J, Wong B, Carriere J, Kokko J (2012) The performance of a high solar fraction seasonal storage district heating system-five years of operation. Energy Proc 30:856-865

Singh H, Saini RP, Saini JS (2010) A review on packed bed solar energy storage systems. Renew Sust Energy Rev 14:1059-1069

Smart Net-zero Energy Buildings Strategic Research Network (SNEBRN) (2015). http://www.solarbuildings.ca/index.php/en/ home/about-us. Oct 2015 
Soares N, Costa JJ, Gaspar AR, Santos P (2013) Review of passive PCM latent heat thermal energy storage systems towards buildings' energy efficiency. Energy Build 59:82-103

Solberg DPW (2010) Exergetic/Environmental sustainability performance assessment for community systems: case studies and simulations. Technical Report for Annex 49: low exergy systems for high performance buildings and communities, energy conservation in buildings and community systems, International Energy Agency. By Thermo-Environmental Systems, Richfield, Minnesota, US, 17 Aug 2010

Soni SK, Pandey M, Bartaria VN (2015) Ground coupled heat exchangers: a review and applications. Renew Sust Energy Rev 47:83-92

Tatsidjodoung P, Le Pierrès N, Luo L (2013) A review of potential materials for thermal energy storage in building applications. Renew Sust Energy Rev 18:327-349

Terziotti LT, Sweet ML, McLeskey JT Jr (2012) Modeling seasonal solar thermal energy storage in a large urban residential building using TRNSYS 16. Energy Build 45:28-31

Tulus V, Boer D, Cabeza LF, Jiménez L, Guillén-Gosálbez G (2016) Enhanced thermal energy supply via central solar heating plants with seasonal storage: a multi-objective optimization approach. Appl Energy 181:549-561

Tveit T, Savola T, Gebremedhin A, Fogelholm C (2009) Multi-period MINLP model for optimising operation and structural changes to CHP plants in district heating networks with long-term thermal storage. Energy Convers Manag 50:639-647

Tyagi VV, Buddhi D (2008) Thermal cycle testing of calcium chloride hexahydrate as a possible PCM for latent heat storage. Sol Energy Mater Sol Cells 92:891-899

van Essen VM, Bleijendaal LPJ, Kikkert BWJ, Zondag HA, Bakker M, Bach PW (2010) Development of a compact heat storage system based on salt hydrates. In: Proceedings of EuroSun 2010: international conference on solar heating, cooling and buildings, Graz, Austria, 28 Sept-1 Oct, 2010, paper 230

van Helden W, Hauer A (2010) Compact thermal energy storage research in the IEA SHC/ECES joint Task 4224. In: Proceedings of EuroSun 2010: international conference on solar heating, cooling and buildings, Graz, Austria, 28 Sept-1 Oct, 2010, paper 231 (abstract)

Varol Y, Koca A, Oztop HF, Avci E (2010) Forecasting of thermal energy storage performance of phase change material in a solar collector using soft computing techniques. Expert Syst Appl $37: 2724-2732$
Veerakumar C, Sreekumar A (2016) Phase change material based cold thermal energy storage: materials, techniques and applications-a review. Int J Refrig 67:271-289

Verma P, Singal SK (2008) Review of mathematical modeling on latent heat thermal energy storage systems using phase-change material. Renew Sust Energy Rev 12:999-1031

Wang E, Fung AS, Qi C, Leong WH (2012) Build-up and long-term performance prediction of a hybrid solar ground source heat pump system for office building in cold climate. In: Proceedings of eSim 2012

Wang H, Yin W, Abdollahi E, Lahdelma R, Jiao W (2015) Modelling and optimization of CHP based district heating system with renewable energy production and energy storage. Appl Energy 159:401-421

Waqas A, Din ZU (2013) Phase change material (PCM) storage for free cooling of buildings-a review. Renew Sustain Energy Rev 18:607-625

Weber R (2010) Long-term heat storage with $\mathrm{NaOH}$. In: Proceedings of EuroSun 2010: international conference on solar heating, cooling and buildings, Graz, Austria, 28 Sept-1 Oct, 2010, paper 234

Weber R, Kerskes H, Drück H, Müller-Steinhagen H (2010) New solar thermal storage concept-combined hot water and sorption store. In: Proceedings of EuroSun 2010: international conference on solar heating, cooling and buildings, Graz, Austria, 28 Sept-1 Oct, 2010, paper 233

Yan C, Shi W, Li X, Wang S (2016) A seasonal cold storage system based on separate type heat pipe for sustainable building cooling. Renew Energy 85:880-889

Yu N, Wang RZ, Wang LW (2013) Sorption thermal storage for solar energy. Prog Energy Combust Sci 39(5):489-514

Zavattoni S, Barbato M, Geissbühler L, Haselbacher A, Zanganeh G, Steinfeld A (2015) CFD modeling and experimental validation of a high-temperature pilot-scale combined sensible/latent thermal energy storage. In: SCCER heat and electricity storage $-2^{\circ}$ symposium, 5-6 May 2015, PSI Villigen, Switzerland

Zhao J, Chen Y, Li X (2008) Optimization for operating modes based on simulation of seasonal underground thermal energy storage. Front Energy Power Eng China 2:298-301

Zhu N, Ma Z, Wang S (2009) Dynamic characteristics and energy performance of buildings using phase change materials: a review. Energy Convers Manag 50:3169-3181 